\title{
Two new species and one new species record of Trichosanthes (Cucurbitaceae) from Vietnam
}

\author{
B.E.E. Duyfjes ${ }^{1}$, M.S. Nuraliev ${ }^{2,3}$, H.T. Luu ${ }^{5}$, N.T. Huynh ${ }^{6}$, V.C. Ngo ${ }^{7}$, \\ A.N. Kuznetsov ${ }^{2,4}$, S.P. Kuznetsova ${ }^{2}$
}

Key words

Cucurbitaceae

new record

new species

Trichosanthes

Vietnam
Abstract Two new species endemic to Vietnam are described: Trichosanthes conferta and Trichosanthes epibracteata. Trichosanthes laceribractea is a new record for Vietnam.

Published on 7 December 2016
Recent botanical collections made during fieldwork in Vietnam (in the frame of the Russian-Vietnamese co-operation) included two new species of Trichosanthes. Moreover, material of a male flowering specimen of Trichosanthes laceribractea, a species hitherto known as rather widespread in SE China, was found, and documented with herbarium collection and ample photographs. This is quite remarkable as the genus was extensively studied for the treatments of the genus in Cucurbitaceae for Flora of Thailand and for Flora Malesiana (De Wilde \& Duyfjes 2008, 2010), and also in a separate article on Trichosanthes in Indochina (De Wilde \& Duyfjes 2012). As regards the new species, comparison with Flora of China (Huang et al. 2011) confirmed that similar plants are not known from China either. Female flowers and fruits of the two new species described here as well as the Vietnamese population of $T$. laceribractea are not known. With the new additions the number of Trichosanthes species in Vietnam has been raised to 15.

The new findings corroborate that the genus Trichosanthes is exceptionally rich in species within Cucurbitaceae.

\section{Trichosanthes conferta Duyfjes, Nuraliev \& Luu, sp. nov. -} Fig. $1 a-f$

Markedly differing in male petals with entire margin (fringed or deeply lacerated in all known Trichosanthes species). - Type: Luu Hong Truong, Huynh Nhan Tri \& Ngo Van Cam 1150 (holo MW; iso L L.3955619, SGN), Vietnam, Kon Tum Province, Kon Plong District, Ngok Tem Commune, N1443'43.3" E108 20'04.3", 1120 m elevation, 18 Apr. 2016, male fl.

Naturalis Biodiversity Center, section Botany, P.O. Box 9517, 2300 RA Leiden, The Netherlands:

corresponding author e-mail: b.dewilde-duyfjes@naturalis.nl.

2 Joint Russian-Vietnamese Tropical Scientific and Technological Center, Cau Giay, Hanoi, Vietnam; e-mail: max.nuraliev@gmail.com.

${ }^{3}$ Faculty of Biology, M.V. Lomonosov Moscow State University, 1, 12, Leninskie Gory, 119234 Moscow, Russia.

${ }^{4}$ A.N. Severtsov Institute of Ecology and Evolution of the Russian Academy of Sciences, Leninsky 33, Moscow, Russia.

${ }^{5}$ Southern Institute of Ecology, Vietnam Academy of Science and Technology, 1 Mac Dinh Chi, District 1, Ho Chi Minh City, Vietnam.

${ }^{6}$ Faculty of Agriculture \& Forestry, Tay Nguyen Technical School for Agriculture and Forestry, 438 Truong Chinh, Pleiku City, Gia Lai Province, Vietnam.

7 Tropical Research Centre, Forest Science Institute of Central Highlands and South of Central Vietnam, Chi Lang Ward, Pleiku City, Gia Lai Province, Vietnam.
Etymology. The specific epithet refers to the crowded flowers in the male inflorescence (Latin: conferta $=$ crowded).

Trailing or climbing subherbaceous perennial (?) vine; stem between adult leaves c. $3 \mathrm{~mm}$ diam, grooved on drying, not reddish tinged; whole plant appearing as glabrous, but sparsely minutely (appressed) greyish-hairy, hairs less than $0.1 \mathrm{~mm}$ long, hairs more obvious in inflorescence; dioecious. Probract linear, 10-12 mm long. Tendrils 2- (or 3-)branched, 10-15 cm long, point of branching 1-3 cm from the base, one branch much longer. Leaves dispersed when trailing, showing up as distichous when creeping (Fig. 1a); petiole c. $2 \mathrm{~cm}$ long, c. $2 \mathrm{~mm}$ diam; lamina brown on drying, thinly coriaceous, entire, ovateelliptic, (8-)10-15 by $4.5-9 \mathrm{~cm}$, glands absent, cystoliths absent, base broadly rounded or shallowly cordate, near the insertion with the petiole with two inconspicuous lobes (not glandular), margin entire, smooth or with remote dents c. $0.5 \mathrm{~mm}$ long, apex acute-acuminate; veins \pm 3 - or 5 -pli-nerved at base and 1 or 2 (or 3 ) pairs from the midrib, tertiary venation coarsely reticulate, raised below. Male raceme minutely grey or pale brown hairy, hairs c. $0.1 \mathrm{~mm}$ long; peduncle straight, c. $10 \mathrm{~cm}$ long, 1.5-2 mm thick, at base co-axillary with or without a single flower-pedicel $6-8 \mathrm{~cm}$ long; rachis short, not thickened, 0.5-1.5 cm long, 8-10-flowered, the flowers condensed, sub-umbellate; bracts persistent (?), narrowly elliptic (leaving sight on younger buds), $10-20$ by c. $2.5 \mathrm{~mm}$, long-narrowed at base, margin entire, apex long-acute, glands minute (but see note 3 ). Male flowers finely grey-brown hairy; pedicel erecto-patent, persistent, $10-15 \mathrm{~mm}$ long, not distinctly articulated to the flower; receptacle tube very minutely hairy inside, long-cupshaped, c. $15 \mathrm{~mm}$ long, at throat c. $8 \mathrm{~mm}$ wide; sepals erect, (long-) triangular, entire, $2.5-3 \mathrm{~mm}$ long, petals in bud outside finely brown hairy, \pm valvate, the bud narrowed (not rounded) towards the apex; petals white, spreading, obovate-oblong, c. $20 \mathrm{~mm}$ long, broadest towards apex where irregularly lobed or undulate, without hair-like threads; stamens 3 (two 2-thecous, one 1-thecous, or occasionally 5 , all 1 -thecous), inserted about halfway to the receptacle-tube, reaching to the throat of the receptacle tube, filaments free, glabrous (glandular hairy), widening to the anthers, anthers 3 , tightly connivent into a broadly ellipsoid synandrium, at apex sterile, flat with some fleshy bulges, anthers two 2-thecous, one 1-thecous, thecae

(c) 2016 Naturalis Biodiversity Center

You are free to share - to copy, distribute and transmit the work, under the following conditions:

Attribution: $\quad$ You must attribute the work in the manner specified by the author or licensor (but not in any way that suggests that they endorse you or your use of the work).

Non-commercia: 
sigmoid, minutely hairy at their margins. Female flower, fruit, and seed not known.

Distribution - S Vietnam, known only from the type locality.

Habitat \& Ecology - Climber on trees along road near river; 1120 m elevation; flowering in April.

Notes -1 . The here presented description of $T$. conferta is based on the herbarium collection Luu Hong Truong et al. 1150 and on photographs made by Luu Hong Truong in the field in 2016 , as well as on those previously made by Nuraliev in 2015 , on the same locality.

Trichosanthes is night-flowering, the petals are white, apparently fading to purplish brown at the end of the night.

2. Trichosanthes conferta resembles most the rather widespread T. truncata C.B.Clarke. The latter species differs in lacking a probract, in longer petioles, shorter and broader male bracts, reflexed sepals, fringed petals, and a more elongate rachis in the male raceme. In $T$. conferta the probract is small and narrow and may be overlooked. The new species has conspicuously straight male peduncles bearing at apex the flowers close together, reminiscent of an umbel, one flower in anthesis each day. The lack of thread-like fringes on the petals is unique in the genus.
3. The male bracts are abaxially covered with numerous minute glands which in fresh leaves look like bright green convex warts, and when dry as pale discs, c. $0.1 \mathrm{~mm}$ diam. They are much smaller than the glands in other species, c. $1 \mathrm{~mm}$ diam or more.

\section{Trichosanthes epibracteata Duyfjes \& Nuraliev, sp. nov. -} Fig. 2, 3a, b

Distinct from Trichosanthes villosa Blume in the much deeper lobed lamina and 3-branched tendril (4-7-branched in T. villosa). - Type: Nuraliev 1222 (holo MW; iso L L.3955617), S Vietnam, Kon Tum Province, Sa Thay District, Ro Koi Municipality, Chu Mom Ray National Park, 33 km WNW of Kon Tum, N14²9'45" E107²43'35", 900 m elevation, 30 Mar. 2015, male fl.

Etymology. The specific epithet refers to the bract shifted up along the floral pedicel (Greek: epi = upon).

Stout perennial climber, c. 10 (?) m long; leafy stem \pm grooved on drying, not reddish tinged, glabrous (glabrescent from minute hairs), c. $4 \mathrm{~mm}$ diam; dioecious. Probract absent, but a brown hairy wart c. $2 \mathrm{~mm}$ diam present (Fig. 2). Tendrils 3-branched, one branch strongest, point of branching c. $2 \mathrm{~cm}$ from the base, brown hairy, hairs c. $0.5 \mathrm{~mm}$ long, glabrescent. Leaves: petiole stout, hairy, c. $8 \mathrm{~cm}$ long, c. $3 \mathrm{~mm}$ diam; lamina brown on drying,
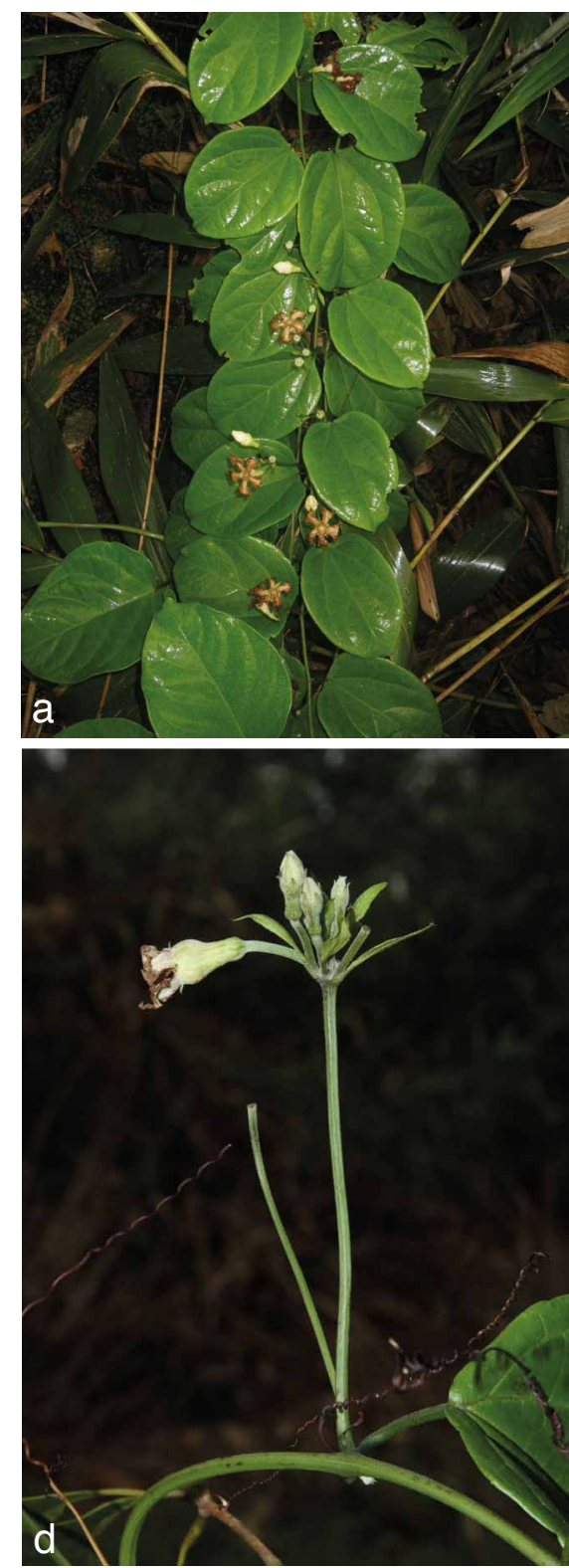
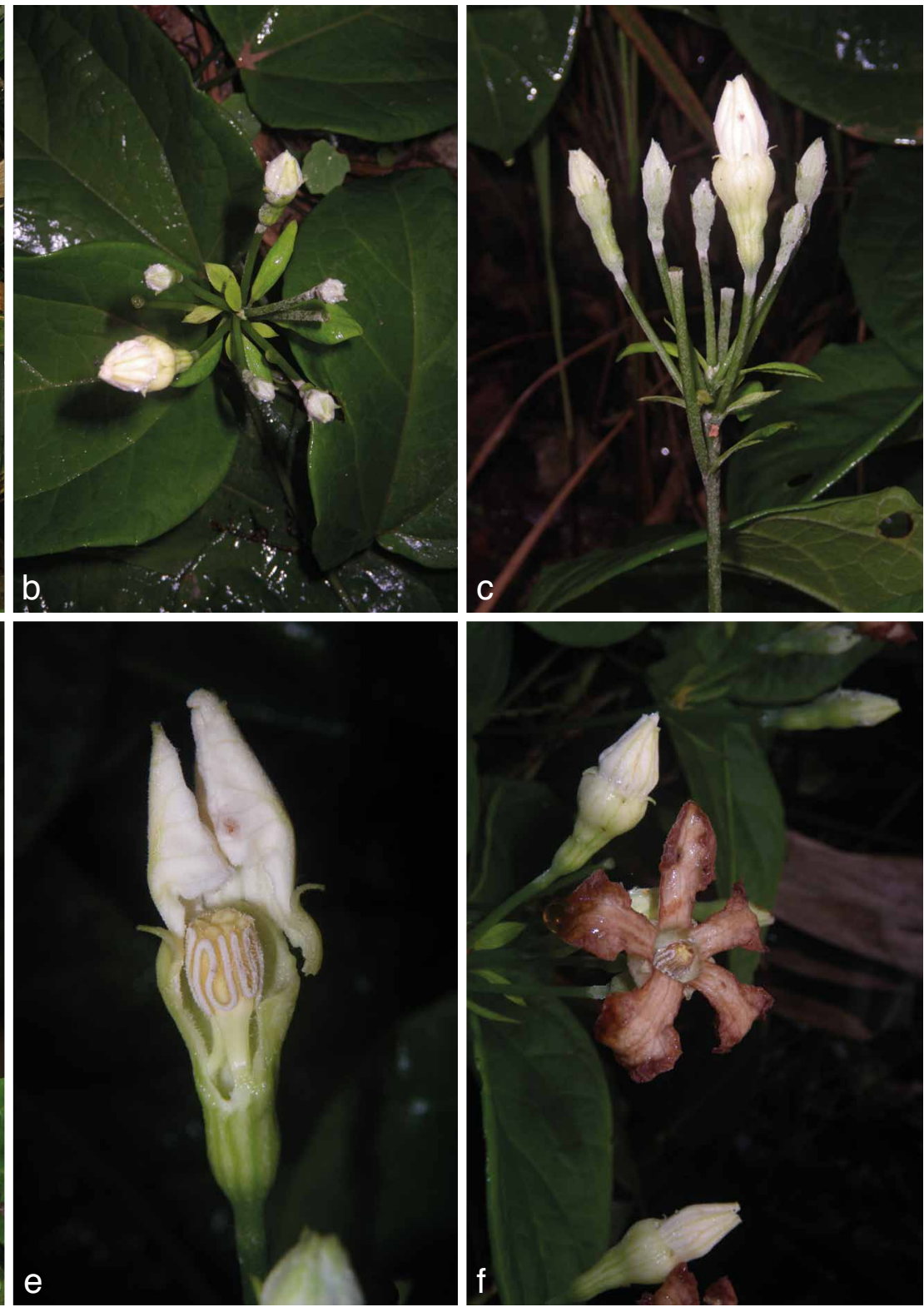

Fig. 1 Trichosanthes conferta Duyfjes, Nuraliev \& Luu. a. Portion of trailing plant; b. male inflorescence; c. idem; d. idem, note pedicel of single basal male flower; e. male bud longitudinally opened showing 3 stamens; f. male flower. — Photos: a-c, f: Maxim Nuraliev; d, e: Hong Truong Luu. 

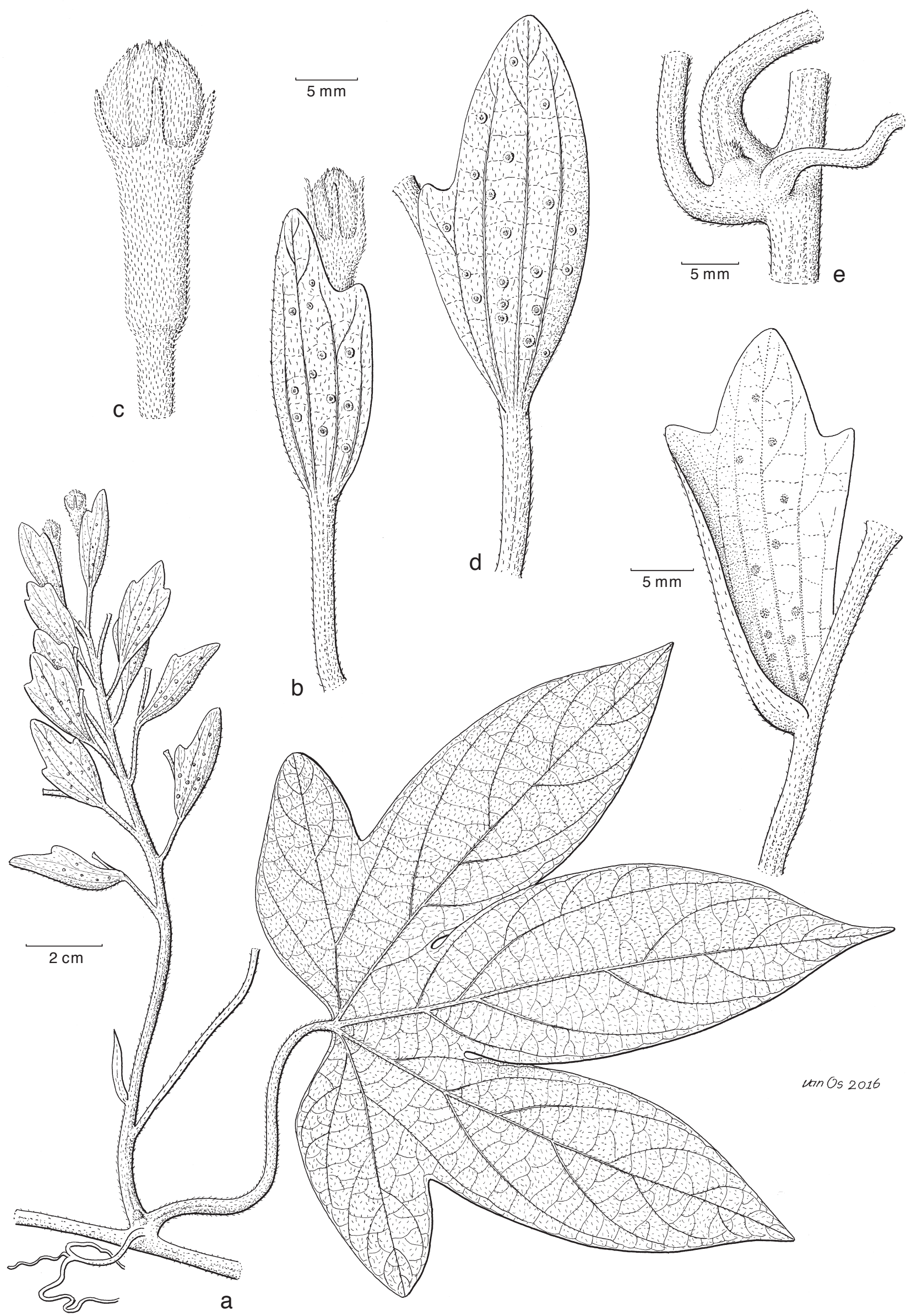

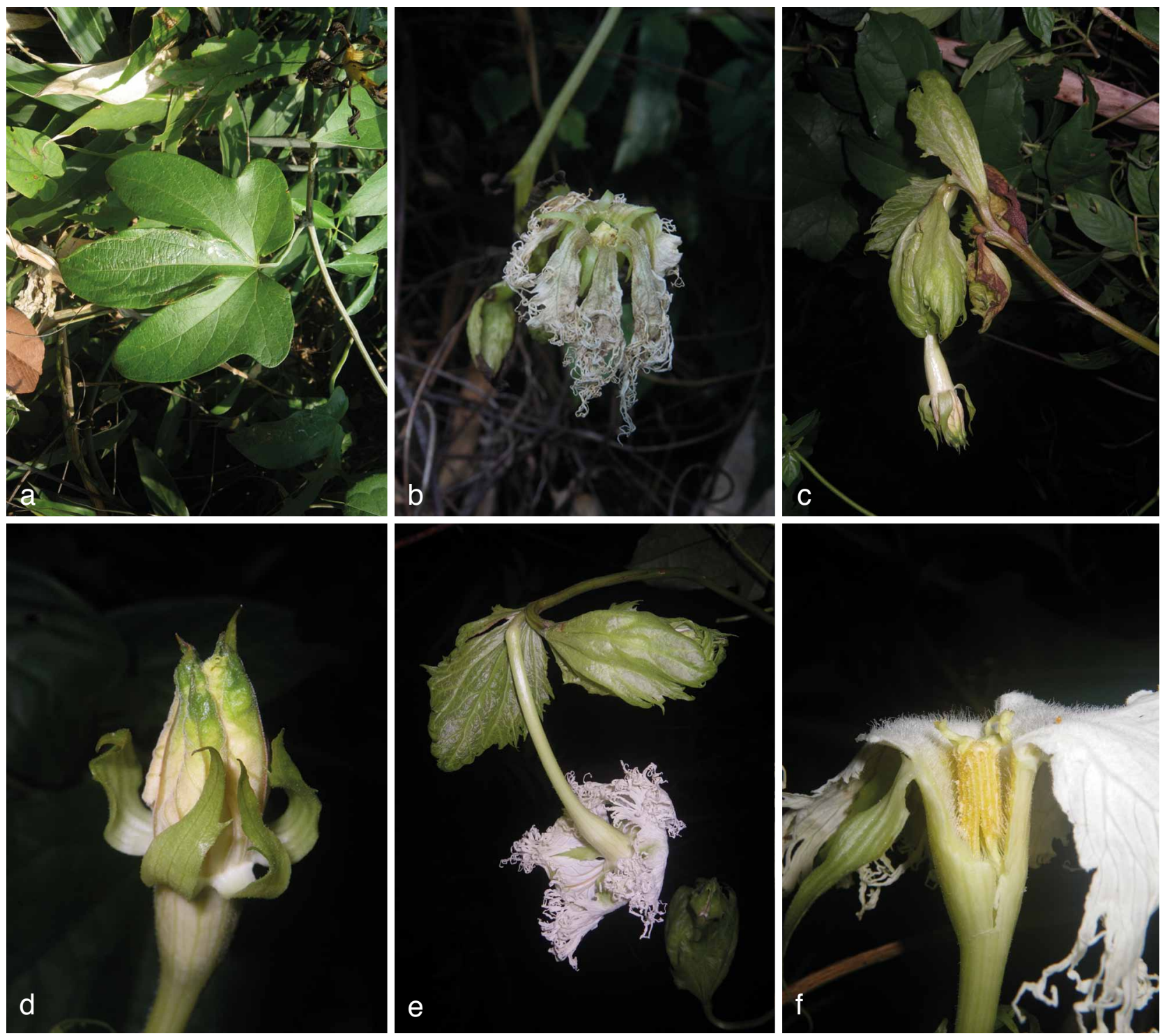

Fig. 3 a, b. Trichosanthes epibracteata Duyfjes \& Nuraliev. a. Leaf; b. male flower. - c-f. Trichosanthes laceribractea Hayata. c. Male inflorescence; d. detail of male bud; e. male flower; f. idem, longitudinally opened, showing hairy tube inside and prolongations of the connectives. — Photos: Maxim Nuraliev.

(sub)coriaceous, deeply 5-lobed to $1 / 2-2 / 3$ deep, outer lobes smaller, in outline subcircular, $14-17 \mathrm{~cm}$ diam, finely bullate and hairy on the veins above, densely hairy all over beneath, glands absent, cystoliths not obvious, base deeply cordate, margin entire, apex of lobes long acute-acuminate; veins and veinlets sunk above, distinctly raised beneath. Male raceme finely brown hairy, co-axillary at the node or slightly adnate to base of peduncle with a single pedicel c. $80 \mathrm{~mm}$ long, the flower not present in the material; peduncle $8-9 \mathrm{~cm}$ long, c. $3 \mathrm{~mm}$ thick, about halfway with 1-3 sterile bracts up to $1.5 \mathrm{~cm}$ long; rachis not thickened, 6-12 cm long, 2.5-3 mm thick, c. 10flowered; bracts persistent, inserted on the pedicel $1-2 \mathrm{~cm}$ from the base, elliptic, $2-2.5$ by $1-1.2 \mathrm{~cm}$, margin subentire, glands numerous. Male flowers: brown hairy; pedicel 20-30 $\mathrm{mm}$ long, persistent, with bract inserted at c. $2 / 3$ from the base; receptacle tube (25-) $30 \mathrm{~mm}$ long, at throat c. $7 \mathrm{~mm}$ wide, bulging to $10 \mathrm{~mm}$ wide above the middle, at base slightly broadened where demarcated with the pedicel; sepals longtriangular to lanceolate, c. $7 \mathrm{~mm}$ long, entire, petals white, obovate or obovate-oblong, $40-50 \mathrm{~mm}$ long including threads c. $20 \mathrm{~mm}$ long; synandrium not seen. Female flower, fruit, and seed not known.

Distribution - S Vietnam, known only from the type locality.

Habitat \& Ecology — Forest margin in logging area; $900 \mathrm{~m}$ elevation; flowering in March.
Note - Trichosanthes epibracteata keys out in the key for Trichosanthes in Indochina (De Wilde \& Duyfjes 2012) beside $T$. villosa Blume, a species also with the male bract considerably shifted upwards on the pedicel. The latter species is readily distinct in an overall weaker appearance, and more precisely in e.g. indumentum of longer hairs, c. $1 \mathrm{~mm}$ long, leaves not or hardly lobed, tendril 4-7(-9)-fid, and missing the hairy wart at the node.

\section{Trichosanthes laceribractea Hayata}

Trichosanthes laceribractea Hayata (1911) 117; C.Jeffrey (1980) 40; H.Y.Liu (1993) 868 ('laceribracteata'); Lu Q.Huang et al. (2011) 43. - Type: Kawakami \& Kobayashi 1589 (TI TI0001071), Taiwan.

Perennial climber c. 10 (?) m long; leafy stem grooved on drying, young twigs, tendrils, petioles, and veins on lamina below reddish tinged, whole plant generally glabrous except the inflorescence, c. $3 \mathrm{~mm}$ diam; dioecious. Probract ovate-elliptic, c. $13 \mathrm{~mm}$ long, subentire. Tendrils 3-branched, one branch strongest, up to $20 \mathrm{~cm}$ long, point of branching $4.5-6 \mathrm{~cm}$ from the base. Leaves: petiole 5-6 cm long, c. $2 \mathrm{~mm}$ diam; lamina brown-green on drying, membranous, (3-)5-lobed for c. 1/3, outer lobes much smaller, in outline subcircular, $13-15 \mathrm{~cm}$ diam, glands $1-2$, flat, $2-3 \mathrm{~mm}$ diam, situated at c. $2 \mathrm{~cm}$ from the insertion of the petiole, cystoliths minute (leaf surface not scabrous), 
base deeply cordate, margin remotely sharp-dentate, apex of lobes abruptly acuminate; veins and veinlets flat above, little raised beneath, veins minutely hairy above and very sparsely so below. Male raceme without a solitary flower co-axillary; peduncle 7-10 cm long, c. $3 \mathrm{~mm}$ diam; rachis not thickened, 4-6 cm long, 2-3 mm diam, 5-10-flowered; bracts subpersistent, elliptic(-obovate), $4.5-6$ by $3-3.5 \mathrm{~cm}$, margin coarsely \pm irregularly serrate-dentate $3-5 \mathrm{~mm}$ deep, glands absent. Male flowers: seemingly glabrous but finely hairy on magnification, see note 4; pedicel 3-4 mm long, persistent; receptacle tube narrow, cylindrical, $55-60(-90) \mathrm{mm}$ long, at throat $6-7 \mathrm{~mm}$ wide; sepals long-triangular, long-acute-acuminate, $18-20$ by c. $5 \mathrm{~mm}$, margin remotely sharply few-dentate; petals white, broadly fan-shaped, c. 35 by $50-55 \mathrm{~mm}$, at apex broad and irregularly and coarsely or finely laciniate-dentate, $5-15 \mathrm{~mm}$ deep; synandrium c. 10 by c. $6 \mathrm{~mm}$, anthers two 2-thecous, one 1-thecous, filaments inserted towards the apex of the receptacle tube, each connective at apex with undulating sterile prolongation c. $5 \mathrm{~mm}$ long. Female flower, fruit, and seed not known in Vietnam.

Distribution - SE China, Taiwan, S Vietnam (Kon Ka Kinh National Park).

Habitat \& Ecology (in Vietnam) - Disturbed forest; 900 m elevation; flowers in May.

Notes - 1. Trichosanthes laceribractea is a new record for Vietnam, only known by the collection Nuraliev 1474 (Gia Lai Province, Mang Yang District, A Yun Municipality, Kon Ka Kinh National Park, 31 km WNW of K'Bang, N14¹2'31" E108¹9'00", 900 m elevation, 13 May 2016; L, MW).

2. Trichosanthes laceribractea keys out in the key to the species of Indochina (De Wilde \& Duyfjes 2012) beside T. fissibracteata C.Y.Wu ex C.Y.Cheng \& C.H.Yueh and T. tricuspidata Lour. The first, $T$. fissibracteata differs in having a linear probract 20-30 mm long, entire leaf margin and deeply laciniate male bracts; T. tricuspidata is distinct in having a smaller probract $5(-10) \mathrm{mm}$ long and smaller blade glands, 0.5-1 mm diam.

3. Trichosanthes laceribractea was described from Taiwan, and occurs rather widespread in SE China. The species was recorded for Vietnam by Jeffrey (1980) based on the collection Pételot 1084, but this collection was later on relegated to T. fissibracteata by De Wilde \& Duyfjes (2012). As can be expected of a collection rather away from China, in the Vietnamese plant some differences can be noticed (seen on the colour photographs): reddish colour of young twigs, tendrils and veins on lamina below, and the presence of fleshy prolongations of the connectives (Fig. 4d). Furthermore, it can be mentioned that the male bracts are longer, $4.5-6 \mathrm{~cm}$ long vs $3-4 \mathrm{~cm}$ long in China. The petals are pure white.

4. The flower shows up as glabrous, but on magnification (Fig. 4d) it can be seen that the flower bud is minutely hairy outside throughout and that the tube inside is long hairy in the broadened part, the petals are long hairy near the throat and shorter hairy adaxially.

5. Flowering phenology (based on observations of the Vietnamese plant): The flower begins to open around 22.00 P.M., full flowering at least between 23.00 P.M. and 2.30 A.M., at 6.30 A.M. the flower is abscised.

During the night the open flowers are visited by numerous small flies of the family Phoridae.

Acknowledgements We are indebted to Tatiana Galinskaya (Department of Entomology, Biological Faculty, Moscow State University) for identification of flies on the photographs of T. laceribractea. The work of M.S. Nuraliev was carried out in accordance to Government order for the Lomonosov Moscow State University Project No. AAAA-A16-116021660045-2. Hong Truong Luu was supported by the project 'Databasing biodiversity of flora and fauna of Kon Ka Kinh National Park and recommending conservation measures' funded by Gia Lai Provincial Department of Science and Technology to the park (Contract no. 09/HD-SKHCN dated 29 July 2014). Finally, the authors thank the artist Jan van Os $(\mathrm{L})$ who made the line drawing and Tetsuo OhiToma (TI) for providing a photograph of the type of T. laceribractea.

\section{REFERENCES}

De Wilde WJJO, Duyfjes BEE. 2008. Cucurbitaceae. Flora of Thailand 9: 411-546. Niran Hetrakul, Prachachon Co. Ltd., Thailand.

De Wilde WJJO, Duyfjes BEE. 2010. Cucurbitaceae. Flora Malesiana, Series I - Seed Plants 19: 1-333. NCB Naturalis Publications Department.

De Wilde WJJO, Duyfjes BEE. 2012. Keys to and checklist of species of the genus Trichosanthes L. (Cucurbitaceae) in Indochina. Adansonia, sér. 3, 34: $265-278$

Hayata B. 1911. Materials for a flora of Formosa. Journal of the College of Science, Imperial University of Tokyo 30: 117.

Huang LQ, Lu AM, Jeffrey C. 2011. Trichosanthes. Flora of China 19: 36-45. Missouri Botanical Garden Press, St. Louis.

Jeffrey C. 1980. The Cucurbitaceae of Eastern Asia: 40. Royal Botanic Gardens, Kew.

Liu HY. 1993. Cucurbitaceae. Flora of Taiwan, second edition: 868. Taipei, Taiwan, ROC 